\title{
James Crawford and the art of law
}

\author{
Hilary Charlesworth*
}

Laureate Professor and Harrison Moore Professor of Law, Melbourne Law School and Distinguished Professor, the Australian National University

Email: h.charlesworth@unimelb.edu.au

James Crawford's death has been marked by tributes from far and wide. These range from the solemn beauty of the International Court of Justice's memorial service, the poignant family service in the Hague, to conference panels, ${ }^{1}$ obituaries, ${ }^{2}$ and memoirs. ${ }^{3}$ A strikingly consistent picture emerges from these diverse sources. It is universally acknowledged that James was a brilliant scholar and peerless advocate before international courts and tribunals. He also possessed great intellectual generosity with a remarkable capacity to bring order, creativity and finality to projects that were foundering. James was an inspiring and energetic teacher, supervisor, and mentor. He nurtured generations of scholars across the globe, including those, like me, with whom he had no institutional affiliation. James's low-key manner and dry humour made him appealing company. Despite his human warmth, James had a reputation for disarmingly honest assessments of academic quality; his written letters of reference, for example, were succinct, frank and unadorned, sought only by the brave.

I first met James in 1980, when I was a law student. I was a member of the University of Melbourne Jessup Moot team and my university was hosting the Australian Jessup competition. In those days, I must admit, this was not at all competitive - I think there were just three or four Australian universities taking part. James was then at Adelaide Law School. Apart from his standing as a scholar, James was considered a font of wisdom on the Jessup Moot as he had coached the Adelaide team all the way to the final round in the international competition the previous year. I had assumed this famous person would be resolutely middle aged, or elderly, to have achieved so much and was surprised by this youthful, energetic presence. James was dressed quite casually, and I first mistook him as a student mooter. But James blew us mooters all away - he was so full of life, so charismatic and so clever. When he acted as a judge in the moots, his understated manner of asking questions (on the international law of outer space) often lulled us into thinking that they could be easily answered. We quickly discovered that James's questions would take us far beyond our limited international legal knowledge. He would firmly, but gently, point out where we had got lost.

${ }^{\star}$ This tribute is based on a contribution to the Australian and New Zealand Society of International Law (ANZSIL) Tribute Panel for James Crawford of 6 July 2021.

${ }^{1}$ E.g., Fifteen Glimpses of James Crawford, ANZSIL, available at www.youtube.com/watch?v=GstAyE2W02c.

${ }^{2}$ E.g., P. Sands, 'James Crawford obituary', The Guardian, 13 June 2021, available at www.theguardian.com/law/2021/jun/ 13/james-crawford-obituary; N. Schrijver and R. Wolfrum, 'In memoriam Judge James Crawford (1948-2021)', Oxford Constitutional Law, 29 July 2021, available at oxcon.ouplaw.com/oxlaw/newsitem/1404/mpeccol-in-memoriam-judgejames-crawford-19482021.

${ }^{3}$ E.g., D. Guilfoyle, 'Vale Judge James Crawford: A model PhD supervisor', Opinio Juris, 2 June 2021, available at opiniojuris. org/2021/06/02/vale-judge-james-crawford-a-model-phd-supervisor/; S. Chesterman, 'Scholar, advocate, judge: James Crawford 1948-2021', The Interpreter, 2 June 2021, available at www.lowyinstitute.org/the-interpreter/scholar-advocatejudge-james-crawford-1948-2021.

(c) The Author(s), 2022. Published by Cambridge University Press on behalf of The Foundation of the Leiden Journal of International Law in association with the Grotius Centre for International Law, Leiden University. 
James had a deep knowledge and appreciation of art, as well as music and literature. One manifestation of his artistic interest was his close attention to all aspects of the artwork he selected for the covers of his books. Indeed, James wrote a charming meditation on the cover of The Cambridge Companion to International Law, which he had edited with Martti Koskenniemi. ${ }^{4}$ The cover features a work of the Italian Futurist artist Gino Severini, 'Red Cross Train Passing a Village', painted in the summer of $1915 .{ }^{5}$ Severini set out to capture the reality of war in his art. This painting conveys the speed of the train through its billowing steam and fractured images of the landscape. Its bright colours celebrate the power of rail transport, but the Red Cross flag, alongside the French flag, on the side of the train suggest a darker side of conflict. James's reflection took the form of an imagined dialogue between him ('a naïve positivist') and Martti ('a wily crit'). It posits a tension between them over whether to depict war (James's preference) or the peaceful 'real life' of a village (Martti's preference). Severini's work finally emerges as a compromise to capture the 'and' in what James calls 'the origin of our subject - War and Peace'. He observes '[a]ll our struggles are about the meaning of that "and".

I treasure a 2018 conversation with James in The Hague about his choice of cover images. James plucked various books from his shelves and asked me if I could see why he had chosen a particular artwork for that book; I failed most of this quiz, missing the subtlety of his choices. James lingered on the British artist Kenneth Martin's work 'Chance, Order, Change 12 (Four Colours)', ${ }^{6}$ which he had used on the cover of his General Course in Public International Law at the Hague Academy in 2013 and which had provided the title of the lectures. ${ }^{7}$ James used different works by Kenneth Martin in each of his 15 lectures, and then asked the students attending the lectures to vote for the image that should adorn the cover of the book. Perhaps it was the bold scarlet lines overlaid on softer green, blue, and purple lines that made 'Chance, Order, Change 12 (Four Colours)' win the ballot. Illustrating his extraordinary intellectual energy, James delivered his Hague lectures while he was arguing before the International Court of Justice in the Whaling in the Antarctic case. ${ }^{8}$

James's General Course is an elegant and passionate account of the discipline of international law, giving the reader a strong sense of his voice and personality. He defends international law from challenges by both realists and critical legal scholars, suggesting that both critiques overplay 'the perceived indeterminacy of our discipline' and thus can be used 'to justify clearly illegal conduct', such as the invasion of Iraq in $2003 .{ }^{9}$ By contrast, James acknowledges the 'open texture' of international law but maintains that it co-exists with a 'reasonably well-defined core' of international legal principles. ${ }^{10} \mathrm{He}$ writes ' $\mathrm{t}$ ] he criticism that international law is indeterminate is valid to a degree, but this does not reduce the efficacy of international law as a system'. ${ }^{11}$ James explains his faith in the international legal process as based on a lifetime's professional experience: 'I have found the forms, procedures and even the ceremonies of international law a more level terrain than others for the expression of collective interests and the satisfaction of collective rights. ${ }^{12}$

'Chance, Order, Change 12 (Four Colours)' [see below] is one of an extensive series of works with a similar title made in the 1970s and 1980s at the end of Martin's life. Martin was associated with the British Constructivist art movement, which used abstraction to reflect industrial society.

\footnotetext{
${ }^{4}$ J. Crawford, 'The Cambridge Companion to International Law: A Cover Story', Cambridge International Law Journal, 28 January 2012, available at www.cilj.co.uk/2012/01/28/the-cambridge-companion-to-international-law-a-cover-story-2/.

${ }^{5}$ G. Severini, 'Red Cross Train Passing a Village' (1915), held in the Guggenheim Museum, New York.

${ }^{6} \mathrm{~K}$. Martin, 'Chance, Order, Change 12 (Four Colours)', (1980) held in the Tate Gallery, London.

${ }^{7}$ J. Crawford, Chance, Order, Change: The Course of International Law (2014).

${ }^{8}$ Whaling in the Antarctic (Australia v. Japan: New Zealand intervening), Judgment on Merits, Judgment of 31 March 2014 ICJ Rep. 2014, at 226.

${ }^{9}$ See Crawford, supra note 7, at 174 .

${ }^{10}$ Ibid., at 23 .

${ }^{11}$ Ibid., at 178 .

${ }^{12}$ Ibid., at 23 .
} 
Constructivism was more concerned with science and technology than with artistic expression, and with collective endeavours rather than individual creativity. To produce the 'Chance, Order, Change' paintings, Martin used graph paper, numbered around the edges where the lines intersected with the boundary. He wrote the numbers on separate small cards, which he placed in a container and proceeded to draw them out randomly. Martin then joined each selected pair of numbers on the grid with a line. While the direction of the lines involved chance, it was up to the artist to decide on the nature of each line, such as its colour, length, scale, and thickness. ${ }^{13}$ Martin rotated the drawing 90 degrees after each set of lines was complete and started the process of linedrawing again, producing the asymmetry of the design. ${ }^{14}$ This process explains the title of the painting series: celebrating the power of chance blended with invention as well as a respect for rules and order and the dynamism of their combination. There could be no better visual illustration of James's conception of international law as a complex mixture of abstract principle, history and imagination, generated by the process of 'claiming, arguing, persuading, disputing ${ }^{15}$ of which he was a master.

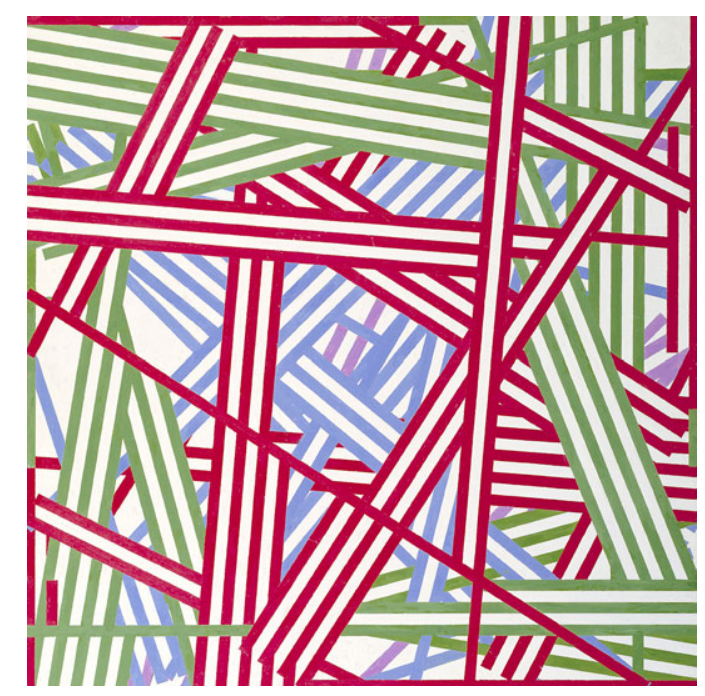

James's Hague Lectures manifest his keen sense of duty towards the discipline of international law as a whole. This included charting its reach and resolving its puzzles, as Sir Kenneth Keith and Bill Campbell have both described in relation to the International Law Commission's Articles on State Responsibility. It also extended to shoring up international institutions and the civil society of international law, including the International Law Association, the Institut de Droit International and the Curatorium of the Hague Academy. While he made weighty contributions to their work, James's interventions at the meetings of these organisations were always pithy and precise; he only spoke when he felt he had something distinctive to add.

For all these reasons, the global international legal community shares a deep sense of loss with James Crawford's death. But this loss must be felt much more acutely by his large extended family,

\footnotetext{
${ }^{13}$ Martin wrote that he realised that he could make a work independent of my personality. I could be the spectator ... These works were not made by knowledge and erudition. All was discarded except a numbered field, the character of the activity of the drawing of lines, and my sense of art'. See www.artscouncilcollection.org.uk/artwork/chance-order-change2-ultramarine-blue.

${ }^{14} \mathrm{~K}$. Martin, Chance Order Change (1982), at 14-15.

${ }^{15}$ Crawford, supra note 7 , at 23.
} 
his seven children and his widow, Freya Baetens. The Crawford family commissioned the Adelaide-based artist, Tsering Hannaford, to paint James's portrait to mark his seventieth birthday in 2018. The painting, on display at James's alma mater, the University of Adelaide, captures James's spirit much better than my written words. In it, we can see beautifully James's intelligence, his humanity, his humour, and his generous and endearing character. 